\title{
THIN LAYER DRYING OF GARLIC SLICES USING INFRARED
}

\author{
I. A. Abdelmotaleb. ${ }^{1}$, M. M. El-Kholy ${ }^{2}$, N. H. Abou-El-Hana ${ }^{3}$, \\ M. A.Younis ${ }^{4}$.
}

\begin{abstract}
Infrared drying of thin layer garlic slices have been studied at four levels of radiation intensity $0.075,0.15,0.225$ and $0.3 \mathrm{~W} / \mathrm{cm}^{2}$, three levels of air velocity $0.25,0.75$, and $1.25 \mathrm{~m} / \mathrm{s}$ and constant air temperature of $\left(40^{\circ} \mathrm{C}\right)$. Three mathematical models (Page, Modified Page, and Henderson and Pabis) were examined for describing the drying behaviour of garlic slices at the above mentioned experimental treatments. The results were compared to their goodness of fit in terms of coefficient of determination $\left(R^{2}\right)$, Standard deviation (SD), the average percentage of error $(\% E)$, Chi-square $\left(\chi^{2}\right)$ and the modeling efficiency $(E F)$. The results showed an increase in drying rate, thermal efficiency, rehydration ratio and colour difference and a decrease in drying time, specific energy consumption, hue angle and the flavour strength with the increase of infrared intensity and decrease of air velocity. Page model showed better prediction of drying process in comparison with the modified Page and the Henderson and Pabis models and it was satisfactorily described the drying behavior of garlic slices under the studied ranges of the experimental treatments. Meanwhile, drying constant of page model $(k)$ increased and the constant (n) decreased with the increase of radiation intensity and the decrease of air velocity.
\end{abstract}

\section{INTRODUCTION}

arlic (Allium Sativum) is a vegetable spice and is used for seasoning of foods because of its typical pungent flavour. It is usually used without any pre processing operation.

1-Prof., and Head of Ag. Eng. Dept., Fac. of Ag., Kaferelsheikh Univ. 2- Senior Researcher, Ag. Eng. Res. Institute, Ag. Res. Center, Dokki, 3- Lecturer, Ag. Eng. Dept., Fac. of Ag., Kaferelsheikh Univ.

4- Ag. Eng., Ag. Eng. Res. Institute, Ag. Res. Center, Dokki, Giza. 
More recently, it has been used in its dried form, as an ingredient of pre cooked foods and instant convenience foods including sauces, gravies and soups, which led to a sharp increase in the demand of the dried garlic (Sharma and Prasad, 2006).

In Egypt, the average cultivated area of garlic vines increased from 23,411 Fed. in 2006 to 32,944 Fed in 2007 with an increase of $40.72 \%$ of the cultivated area. Also, the production increased from 217,194 ton in 2006 to 308,812 tons in 2007 , with an increase of $42.18 \%$ over the same period (IIAS, 2007).

Jones, (1992) noted that there is tremendous loss of thermal energy in the convective drying, making it less efficient process. When infrared radiation is used to heat or dry moist materials, the radiation impinges the exposed material, penetrates it and the energy of radiation converts into heat. Since a material is heated intensely, the temperature gradient in the material reduces within short period. Therefore, energy consumption in infrared drying is relatively lesser. Infrared energy is transferred from the heating element to the product surface without heating the surrounding air.

Mongpreneet et al. (2002) found that the use of infrared radiation in dehydrating foods has several advantages. These may include decreased drying time, high energy efficiency, high quality finished products, uniform temperature in the product while drying, and a reduced necessity for air flow across the product.

Afzal and Abe (2000) reported that air velocity during convective grain drying in thin layers has little influence (would normally increase although may not substantial) on the moisture removal rate.

Jayas and Sokhansanj (1989) mentioned that, contrary to convective drying, an increase in air velocity during far infrared (FIR) drying of barley decreased the drying rate. Increasing air velocity at a given radiation intensity resulted in lowering of kernel temperature and hence, the drying rate. The observed material temperature was low with the increase in air velocity at all levels of radiation intensity.

Abe and Afzal (1997) reported that inlet air temperature between 30 and $40{ }^{\circ} \mathrm{C}$ has no effect on drying rates. They could describe the thin layer drying of rough rice using infrared radiation and established a drying 
equation. The Page model was found to be the most adequate for describing the thin layer drying of rough rice using infrared radiation.

The present study aims to test and to evaluate the effect of different levels of infrared radiation intensity and air velocity on drying characteristics and quality changes of thin layer garlic slices. More over, three different drying models were examined for describing and predicting the changes in moisture content of garlic slices during the drying process.

\section{MATERIALS AND METHODS}

Freshly-harvested garlic cloves (Allium Sativum) were used for the experimental work. The initial moisture content of the freshly harvested garlic ranged from $69 \%$ to $72 \%$ (wet basis) and the drying runs were stopped when the final moisture content reached about $6 \%$ (w.b.).

The experimental apparatus used for the drying process is shown in Figure (1). The drying chamber constructed of $1.5 \mathrm{~mm}$ galvanized metal sheet with $40 \times 28 \mathrm{~cm}$ cross section and $40 \mathrm{~cm}$ high. It was covered from inside with aluminum foil sheets to reflect the radiation flux incident over the garlic slices. Two infrared halogen lamps $(500 \mathrm{~W})$ were assembled inside the drying chamber as a source of infrared radiation. The drying chamber was connected with two electric heaters of $1.35 \mathrm{~kW}$ for each. The heaters were assembled in two series of insulated wooden boxes and connected to the air supply pipe to furnish the required level of air temperature. Air velocity through the drying chamber was controlled through an air valve. A sample holding tray of $20 \times 20 \times 1 \mathrm{~cm}$ was placed facing the infrared lamps at a distance of $15 \mathrm{~cm}$ and supported on an electronic balance to enable recording the mass change of samples during the drying process.

The experimental runs were conducted at constant inlet air temperature of about $40^{\circ} \mathrm{C}$ using a precious digital thermostat as recommended by (Abe and Afzal, 1997). Four levels of radiation intensity (0.075- $0.15-$ $0.225-0.3$ watt $\left./ \mathrm{cm}^{2}\right)$ and three levels of air velocity of $(0.25,0.75$, and $1.25 \mathrm{~m} / \mathrm{s}$ ) were tested and evaluated. A sample size of $100 \mathrm{~g}$ garlic slices was used in each drying run. The peeled cloves were sliced to the desired thicknesses of $(2.5 \pm 0.5 \mathrm{~mm})$. 


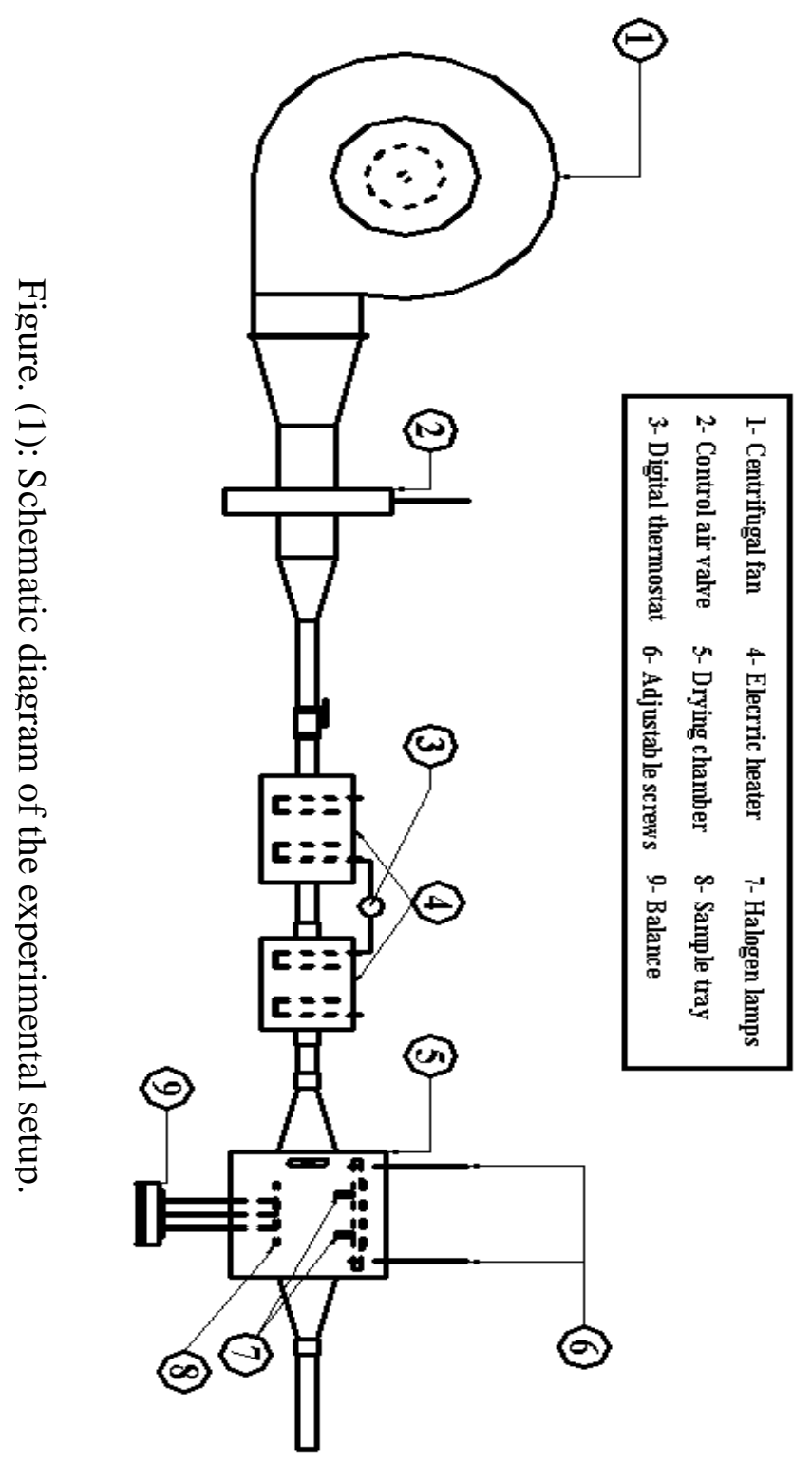


The mass of the samples was recorded using a digital balance with an accuracy of $0.01 \mathrm{~g}$. The balance used for determining the initial and the final mass of sample, and the mass changes through out the experimental runs. The mass changes measurements were used for calculating the change of samples moisture content in wet bases. While, the initial moisture content of garlic were determined on a wet basis by the method described by A.O.AC. (1995) using a vacuum oven at $70^{\circ} \mathrm{C}$ and gauge pressure of $85 \mathrm{kPa}$ for $24 \mathrm{hrs}$.

Changes in mass loss of samples were recorded without removing the sample from the drying chamber.

\section{The Examined Drying Models for Simulating the Drying Data:}

To find the most convenient drying model describing the drying behaviour of garlic slices, three different drying models shown in Table (1) were examined for fitting the drying data. The moisture ratio usually expressed as $\left(\mathbf{M}-\mathrm{M}_{\mathrm{e}}\right) /\left(\mathrm{M}_{\mathrm{o}}-\mathrm{M}_{\mathrm{e}}\right)$. However, it could be simplified to $\mathrm{M}$ / $\mathrm{M}_{\mathrm{o}}$, because the relative humidity of the drying air continuously fluctuated under the tested drying condition and the relatively small value of $\mathrm{M}_{\mathrm{e}}$ compared to $\mathrm{M}$ and $\mathrm{M}_{0}$ as mentioned by (Sacilik and Unal,2005).

Table (1): The mathematical models used for describing the drying data.

\begin{tabular}{|l|l|l|}
\hline \multicolumn{1}{|c|}{ Model } & \multicolumn{1}{c|}{ Equation } & \multicolumn{1}{c|}{ References } \\
\hline Page & $M R=\exp \left(-k t^{n}\right)$ & Page (1949) \\
\hline Modified Page & $M R=\exp \left(-(k t)^{n}\right)$ & Overhults et al. (1973) \\
\hline Henderson and Pabis & $M R=a \exp (-k t)$ & Henderson and Pabis (1961) \\
\hline
\end{tabular}

where:

$\mathrm{MR}=$ The moisture ratio;

$\mathrm{M}=$ The moisture content, \%(w.b.) at time t;

$\mathrm{M}_{\mathrm{o}}=$ The initial moisture content at zero time, \%(w.b.);

$\mathrm{M}_{\mathrm{e}}=$ Equilibrium moisture content, \% (w.b.);

$\mathrm{K}=$ The drying constant;

$\mathrm{n}$ and $\mathrm{a}=$ experimental constants.

The results were compared to their goodness of fit in terms of coefficient of determination $\left(\mathrm{R}^{2}\right)$, Standard deviation (SD), the average percentage of error $(\% \mathrm{E})$, chi-square $\left(\chi^{2}\right)$ and the modeling efficiency (EF). Meanwhile, the regression analysis was also used to develop equations for relating the experimental parameters. 


\section{Energy Requirement:}

The energy consumption during the drying process is the sum of the energy required for heating the ambient air and the supplied net infrared energy. For each experimental run, the power consumption was calculated using the following relationship (Afazl et al., 1999):

$$
\text { Power }=I \times V \times P F
$$

Where:

$$
\begin{aligned}
& \text { Power }=\text { Power consumption }(\mathrm{W}), \\
& V \quad=\text { voltage }(\mathrm{v}), \\
& I \quad=\text { amperage }(\mathrm{A}), \text { and } \\
& P F \quad=\text { power factor, assumed to be one. }
\end{aligned}
$$

The consumed energy was also related to the quantity of lost water and expressed as energy consumption rate (specific energy consumption) in $\mathrm{MJ} / \mathrm{kg}$ of water.

\subsubsection{Thermal Efficiency:}

The thermal efficiency was calculated using the following relationship according to (Reys and Jindal, 1986)

$$
E_{t}=\left(W_{W} \times \frac{L h}{Q}\right) \times 100
$$

Where:

$$
\begin{aligned}
& E_{t}=\text { Thermal efficiency, } \% \\
& W_{W}=\text { Water evaporated from the product, } \mathrm{kg} \\
& \text { Lh = Latent heat of evaporation of water, } \mathrm{kJ} / \mathrm{kg} \\
& \mathrm{Q}=\text { Total energy consumption, } \mathrm{kJ}
\end{aligned}
$$

Latent heat was calculated according to the following formula (Hall, 1970):

$$
\frac{\text { Latent heat of proudct }}{\text { Latent heat of free water }}=1+23 e^{-0.4 M}
$$

Where:

$$
\mathrm{M}=\text { Moisture content in percent, d.b. }
$$

\section{Rehydration ratio measurement:}

Rehydration ratio of the dried garlic slices was determined in triplicate. The rehydration capacity was evaluated by immersing $5 \mathrm{~g}$ of the dried samples into $250 \mathrm{ml}$ laboratory glass containing $150 \mathrm{ml}$ of distilled water and then boiled for $3 \mathrm{~min}$. Sample was taken out, blotted with paper 
towel to eliminate surface water and then reweighed (Sacilik and Unal, 2005). The rehydration ratio was calculated using Equation (4).

$$
\text { Rehydration ratio }=\left(\frac{W_{t}-W_{d}}{W_{d}}\right)
$$

$$
\begin{aligned}
& \mathrm{W}_{\mathrm{t}}=\text { weight of the rehydrated sample, }(\mathrm{g}) \text {, and } \\
& \mathrm{W}_{\mathrm{d}}=\text { weight of the dried sample, }(\mathrm{g}) .
\end{aligned}
$$

\section{Flavor strength measurement:}

The volatile oil comprising of sulfur compounds which are responsible for pungency of the garlic was determined by Chloramine-T method (Shankaranarayana et al., 1981). The volatile oils in the samples were expressed as mg oil/g dry matter.

\section{Colour of the dried garlic:}

The appearance of both fresh and dehydrated slices was assessed by a colour-difference meter using a Hunter Lab Colorimeter. The colorimeter was calibrated against a standard calibration plate of a white surface with $\mathrm{L}, \mathrm{a}, \mathrm{b}$ values of $91.10-0.64$ and -0.43 respectively. (Sharma and Prasad, 2006).

Colour difference $\Delta \mathrm{E}$ and hue angle $\mathrm{H}$ were determined using the following equations:

$$
\begin{aligned}
\Delta \mathrm{E} & =\sqrt{\left(\mathrm{L}_{0}-L_{f}\right)^{2}+\left(a_{0}-a_{f}\right)^{2}+\left(b_{0}+b_{f}\right)^{2}} \\
H & =\tan ^{-1}\left(\frac{b}{a}\right) \quad \ldots \ldots \ldots \ldots \ldots \ldots \ldots \ldots \ldots \ldots \ldots \ldots \ldots \ldots \ldots \ldots \ldots \ldots \ldots \ldots
\end{aligned}
$$

where: $\Delta \mathrm{E}$ is the colour difference; $\mathrm{H}$ is the hue angle in degree; $\mathrm{L}_{0}, \mathrm{a}_{0}$ and $b_{0}$ are the colour lightness, green-red and blue-yellow chromaticity of raw garlic; and $L_{f}$, $a_{f}$ and $b_{f}$ are the colour lightness, green-red and blueyellow chromaticity of dehydrated garlic, respectively. The raw garlic slices were used as the reference and a higher $\Delta \mathrm{E}$ stand for greater colour change from the reference material. The values of $0,90,180$ and $270^{\circ}$ for $\mathrm{H}$ represent red, yellow, green and blue, respectively.

\section{RESULTS AND DISCUSSION}

Figure (2) illustrates the changes of slices temperature as related to drying time at different radiation intensity and air velocity. Increasing the 
radiation intensity tended to increase the garlic slices temperature. However, increasing the air velocity decreased the garlic slices temperature due to the cooling effect of the high velocity air. At the minimum air velocity of $0.25 \mathrm{~m} / \mathrm{s}$, the overall average slices temperatures during the drying process were $74.6,81.8,96.3$ and $113.8{ }^{\circ} \mathrm{C}$ at the minimum radiation intensity of $0.075 \mathrm{~W} / \mathrm{cm}^{2}$, while, at the maximum air velocity of $1.25 \mathrm{~m} / \mathrm{s}$ the corresponding slices temperature were 67.8 , $72.1,79.1$ and $85.9{ }^{\circ} \mathrm{C}$ at the maximum radiation intensity of $0.3 \mathrm{~W} / \mathrm{cm}^{2}$.

\section{Moisture ratio of Garlic Slices:}

Figure (3) illustrates the changes of moisture ratio as related to drying time at different radiation intensity and air velocity. This figure shows that, the moisture ratio of garlic slices decreased with the increase of drying time. As the radiation intensity increased and the air velocity decreased, a high heat flux provided by the infrared source culminated in rapid rise of garlic slices temperature toward the end of the drying process and causes a noticeable reduction of drying time. Changing the radiation intensity from 0.075 to $0.3 \mathrm{~W} / \mathrm{cm}^{2}$ at the minimum air velocity of $0.25 \mathrm{~m} / \mathrm{s}$ decreased the drying time from 100 to $20 \mathrm{~min}$. While, at the maximum air velocity of $1.25 \mathrm{~m} / \mathrm{s}$ it was decreased from 240 to $40 \mathrm{~min}$. These results showed the great effect of air velocity on drying time.

\section{Evaluation of the Studied Models:}

In order to predict the changes in moisture content of garlic slices as a function of drying time, Page, modified Page and Henderson and Pabis models were examined.

To visualize the suitable mathematical expressions, the three models were linearized as follows:

$$
\begin{aligned}
& \ln [-\ln (M R)]=\ln k+n \ln t \ldots \ldots \ldots \\
& \ln [-\ln (M R)]=n_{m} \ln k_{m}+n_{m} \ln t \\
& \ln (M R)=\ln a-k_{h} t \quad \ldots \ldots \ldots \ldots \ldots \ldots
\end{aligned}
$$

The multiple linear regression analysis was used to develop relationship between the parameters of the models and the drying treatments. Drying constants of Page and modified page models were obtained by applying linear regression analysis to the values $\ln (-\ln (\mathrm{MR}))$ and the corresponding drying time. 

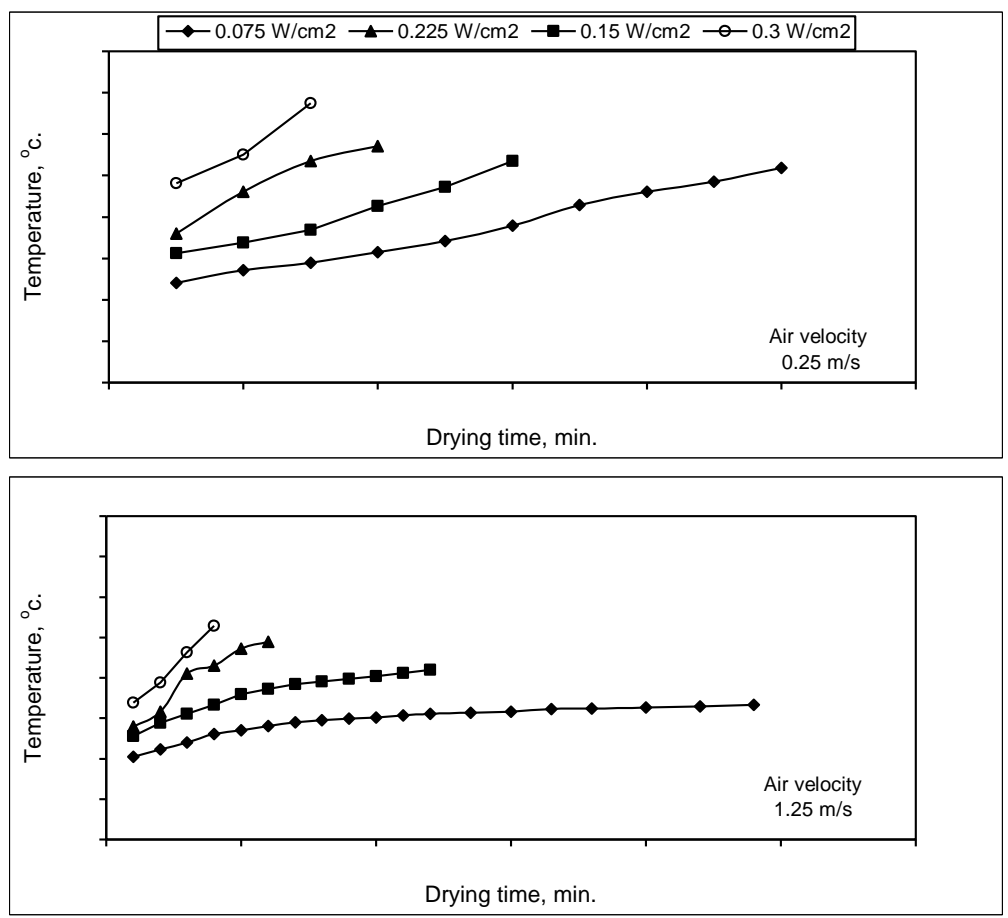

Figure (2): Slices temperature at different radiation intensity and air velocity. 
For the page model, the slope of the fitted line represented the constant (n), while the intercept represents the value of the constant $(\mathrm{k})$ (Equation 7). While, for the modified page model, the slope of the fitted line represented the constant $\left(\mathrm{n}_{\mathrm{m}}\right)$, while the intercept represents the value of the constant $\left(\mathrm{k}_{\mathrm{m}}\right)=\left(\mathrm{n}_{\mathrm{m}} \ln \mathrm{k}_{\mathrm{m}}\right) / \mathrm{n}_{\mathrm{m}}$ (Equation 8). On the other hand, the value of the drying constant of modified Henderson and Pabis model $\left(\mathrm{k}_{\mathrm{h}}\right)$ and (a) were obtained by applying linear regression analysis to the values $\ln (\mathrm{MR})$ and the corresponding drying time (Equation 9). The slope of the fitted line represented the constant $\left(\mathrm{k}_{\mathrm{h}}\right)$, while the intercept represents the value of the constant (a).

The statistical analysis were used for data fitting of the three models are summarized in Table (2). As shown in the table, all the studied models gave consistently high coefficient of determination $\left(\mathrm{R}^{2}\right)$ in the range from 0.9973 to 0.9997 . This means that all the models could satisfactorily describe the drying behavior of garlic slices under infrared heating method. However, among the three studied models, the Page model showed the highest coefficient of determination $\left(\mathrm{R}^{2}\right)$ of 0.9997 , the highest modeling efficiency (EF) of 0.9998 , the lowest standard deviation (SD) of 0.0033 , the lowest average percentage error (E) of 0.0353 and the lowest Chi-square $\left(\chi^{2}\right)$ of $2.03 \times 10^{-5}$.

Thus, this model may be assumed to preciously describe the thin layer drying behaviour of the garlic slices under the studied ranges of experimental treatments.

Plots of the experimental and the predicted moisture ratio with drying time are shown in Figures (4) to (6). As it can be observed in these figures, the Page model provided a good agreement between the experimental and the predicted data in comparison with other two models.

\section{Drying constants of Page model:}

The drying constants $(\mathrm{k})$ and $(\mathrm{n})$ were related to the radiation intensity (I) and air velocity (V). As shown in Figures (7) and (8), the drying constant $(\mathrm{k})$ increased with the increase of radiation intensity and the decrease of air velocity while, the parameter (n) decreased with the increase of radiation intensity and the decrease of air velocity. A simple regression analysis was employed to relate the drying parameters with 

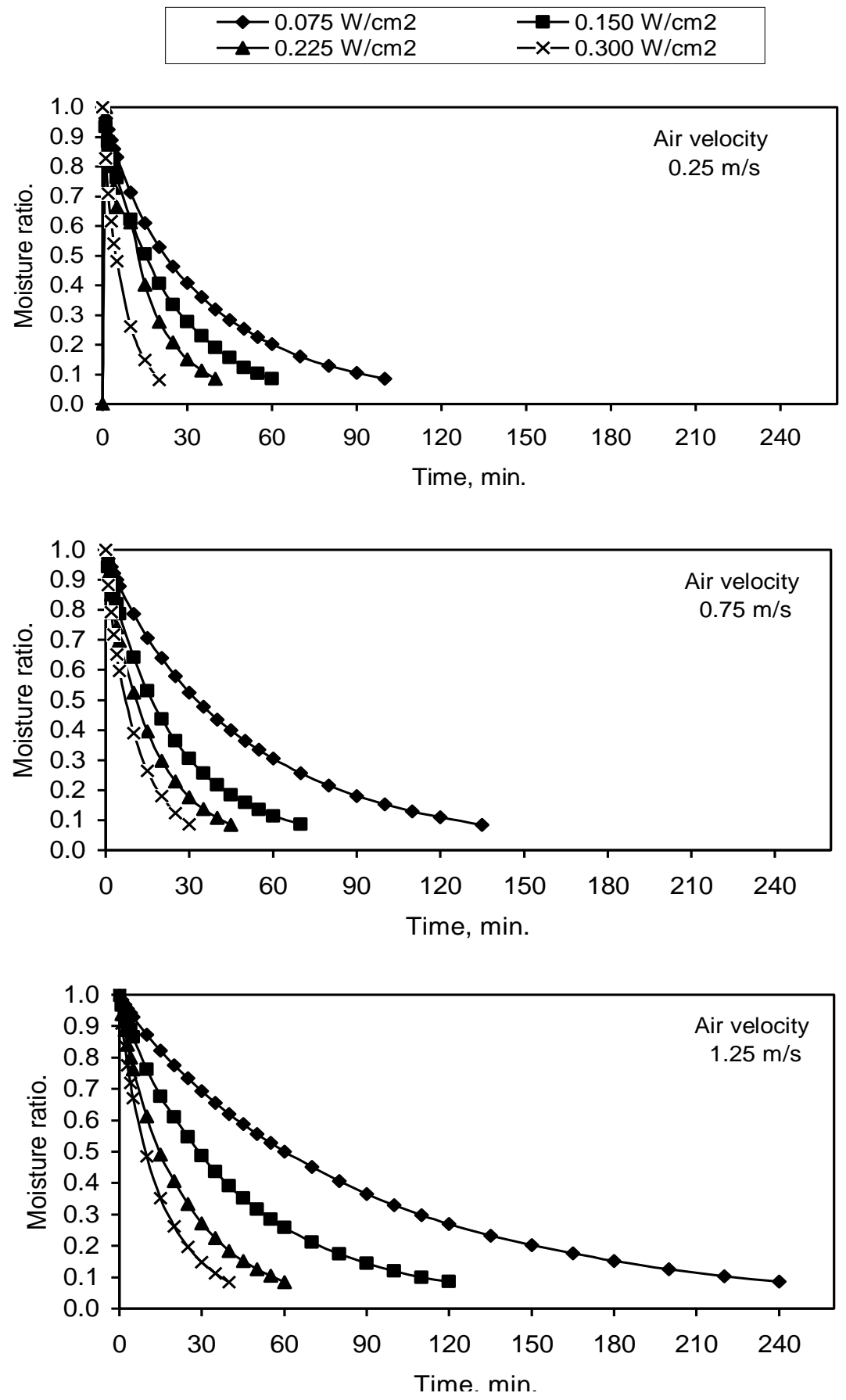

Figure (3): Effect of drying time on moisture ratio of garlic slices at different radiation intensity and air velocity. 
Table(2): Statistical results obtained from different thin layer drying models and the drying constants for infrared drying.

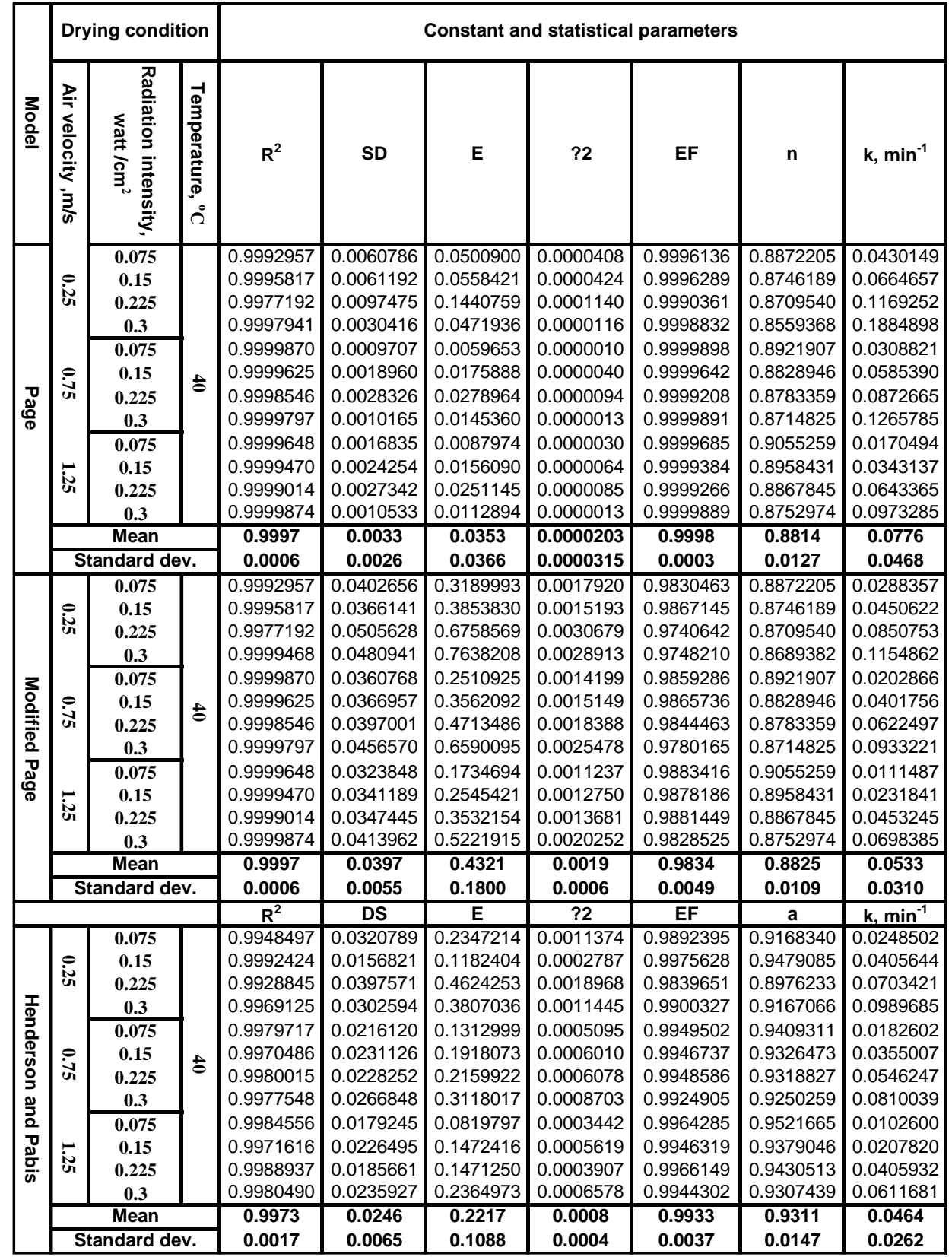



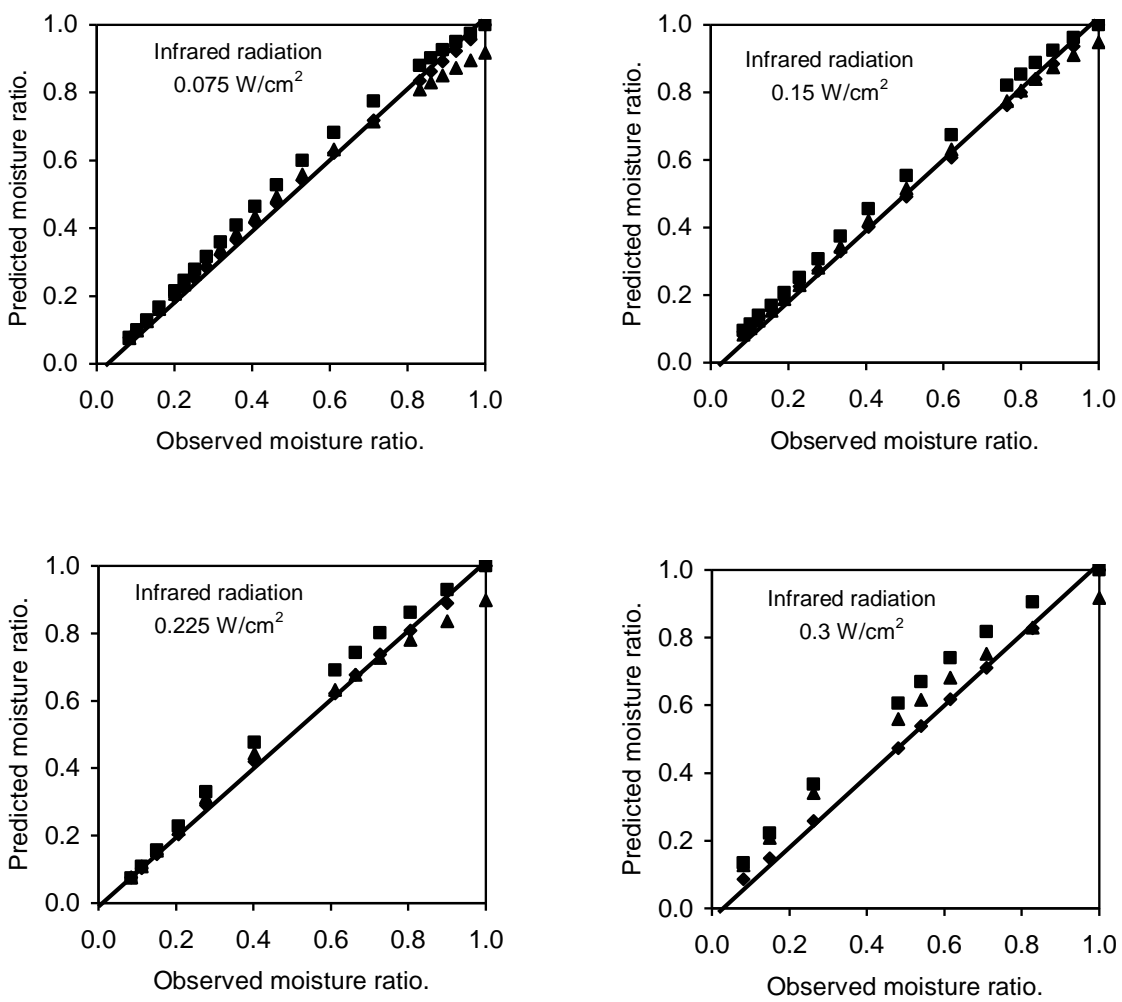

Figure (4): Observed and predicted moisture ratio for different radiation intensity and air velocity of $0.25 \mathrm{~m} / \mathrm{s}$. 

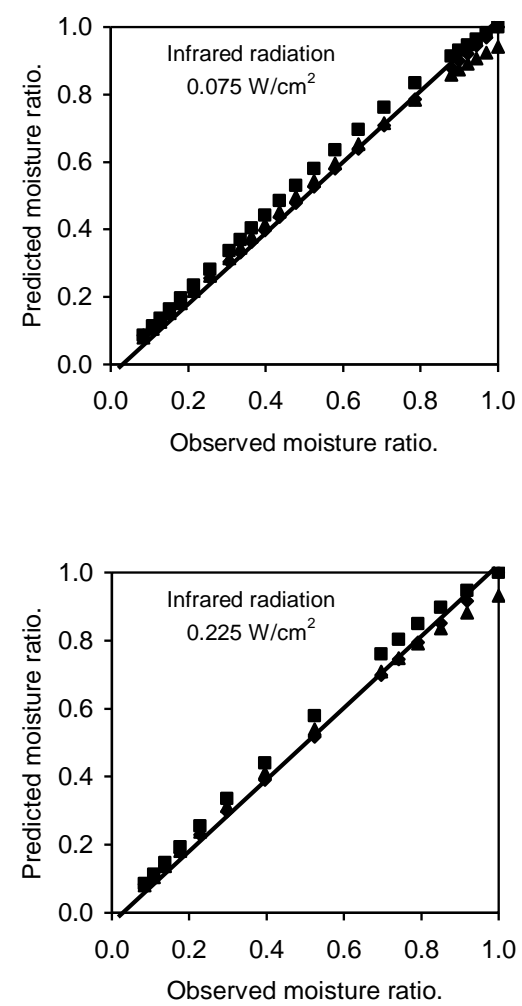
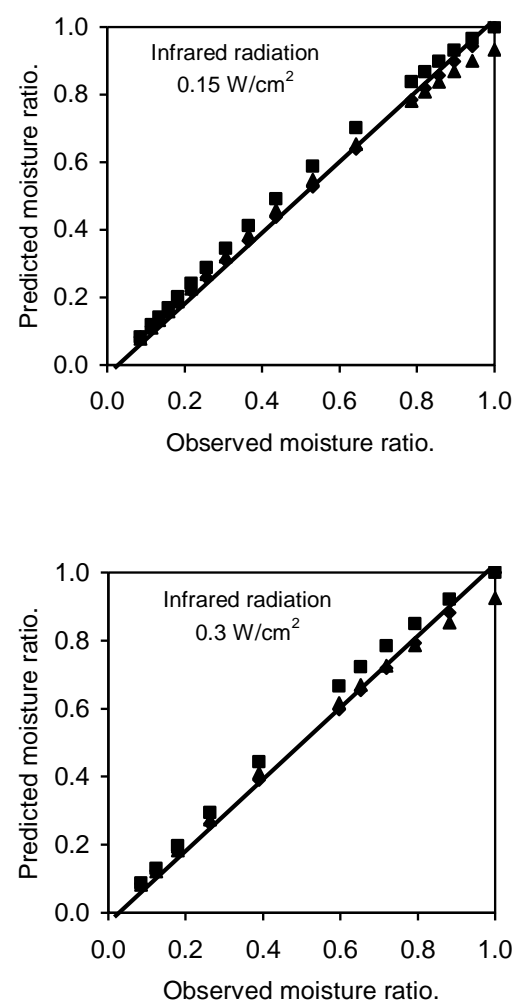

Figure (5): Observed and predicted moisture ratio for different radiation intensity and air velocity of $5 \mathrm{~m} / \mathrm{s}$. 


\section{- Page $\quad$ Modified Page $\Delta$ Henderson and Pabis}
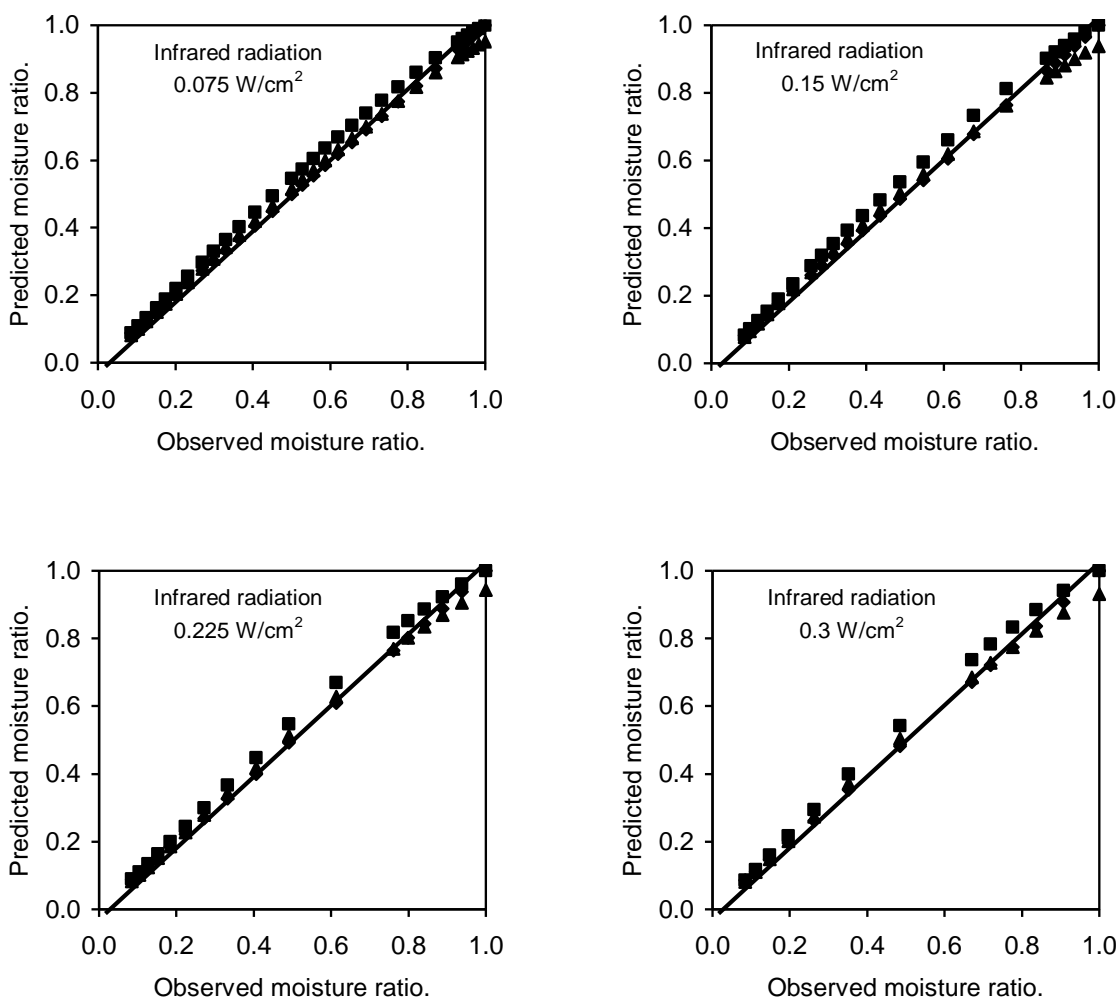

Figure (6): Observed and predicted moisture ratio for different radiation intensity and air velocity of $1.25 \mathrm{~m} / \mathrm{s}$. 


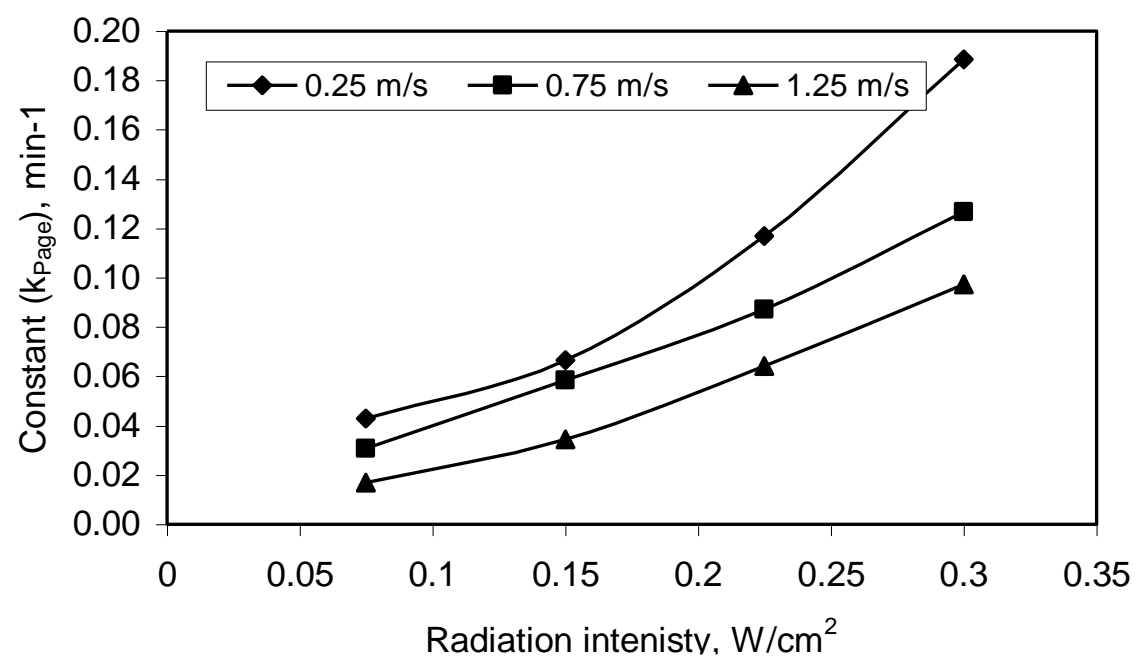

Figure (7): Effect of radiation intensity on the drying constant kpage at different levels of air velocity.

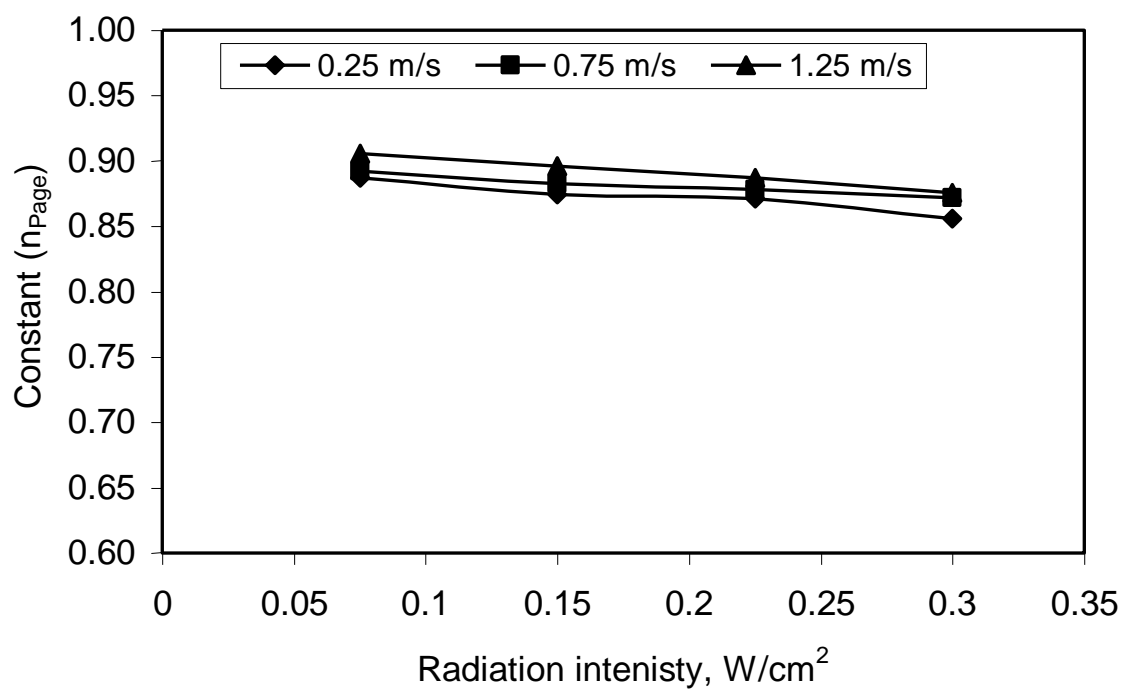

Figure (8): Effect of radiation intensity on the parameter $n_{\text {Page }}$ at different levels of air velocity. 
the drying constants $(\mathrm{k})$ and $(\mathrm{n})$ using the multiple linear regression analysis. The analysis showed a positive linear relationship between the radiation intensity (I) and the drying constant $\left(\mathrm{k}_{\text {Page }}\right)$ and a negative linear relationship between the radiation intensity and parameter ( $n_{\text {Page }}$ ) as presented in Eq. (10) and (11).

$$
\begin{array}{ll}
k=2.6 \times 10^{-2}-5.04 \times 10^{-2} V+0.48 I, & \left(\mathrm{R}^{2}=0.9238\right) \ldots \ldots \ldots \ldots(10) . \\
n=0.89+1.86 \times 10^{-2} V-0.117 I, & \left(\mathrm{R}^{2}=0.9678\right) \ldots \ldots \ldots \ldots .(11) .
\end{array}
$$

\section{Energy consumption:}

Figure (9) illustrates the effect of radiation intensity and air velocity on specific energy consumption. A reduction in specific energy consumption was observed with the increase of radiation intensity and the decrease of air velocity. At the minimum air velocity of $0.25 \mathrm{~m} / \mathrm{s}$ increasing the radiation intensity from 0.075 to $0.3 \mathrm{~W} / \mathrm{cm}^{2}$ decreased the specific energy consumption from 3.44 to $3.12 \mathrm{MJ} / \mathrm{kg}$ water. While, at the maximum air velocity of $1.25 \mathrm{~m} / \mathrm{s}$, the specific energy consumption decreased from 18.32 to $8.27 \mathrm{MJ} / \mathrm{kg}$ water. This means that, the increase of air velocity decreased the garlic slices temperature and hence, increased the drying time and the specific energy consumption as mentioned by (Abe and Afzal,1997).

\section{Thermal Efficiency:}

Figure (10) shows the effect of radiation intensity and air velocity on the dryer thermal efficiency. Thermal efficiency increased with the increase of radiation intensity. Increasing the radiation intensity from 0.075 to 0.3 $\mathrm{W} / \mathrm{cm}^{2}$ at the minimum air velocity of $0.25 \mathrm{~m} / \mathrm{s}$ increased the thermal efficiency from 73.8 to $78.6 \%$. While, it was increased from 13.8 to 30.6 $\%$ at the maximum air velocity of 1.25 .

\section{Garlic Slices Quality:}

\section{Rehydration of Garlic Slices:}

Figure (11) presents the effect of infrared radiation and air velocity on rehydration ratio of the dried garlic slices. This figure shows an increase in the rehydration ratio with the increase of radiation intensity and the decrease of air velocity. This is due to the increased rate of moisture removal with the increase of radiation intensity which causes less shrinkage of the dried slices, thus facilitating the rehydration process. Similar result has been reported by Sacilik and Unal, 2005 for garlic and 


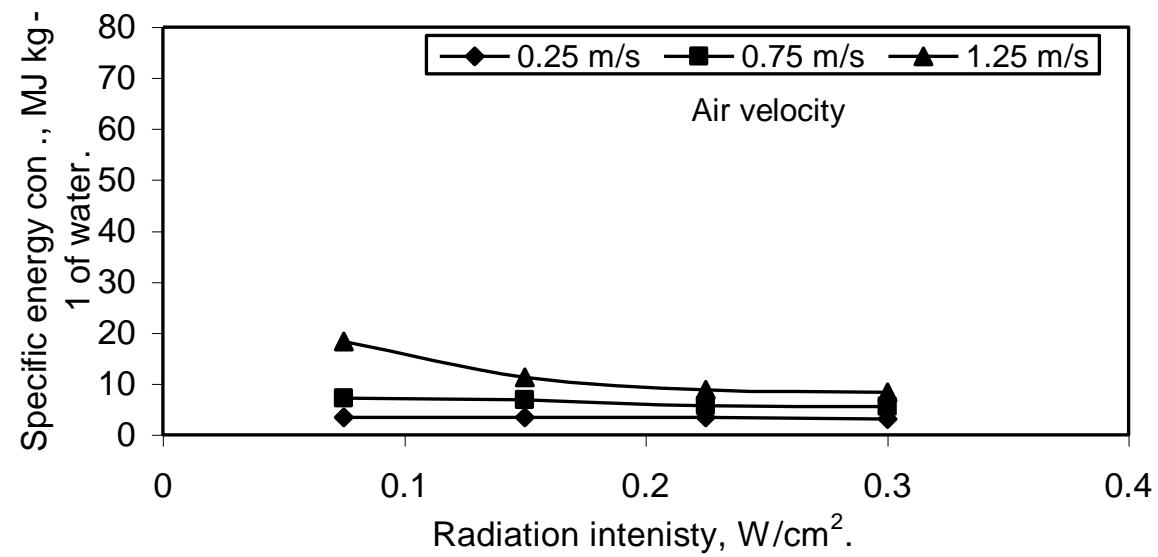

Figure (9): Effect of radiation intensity on the specific energy consumption at different air velocity.

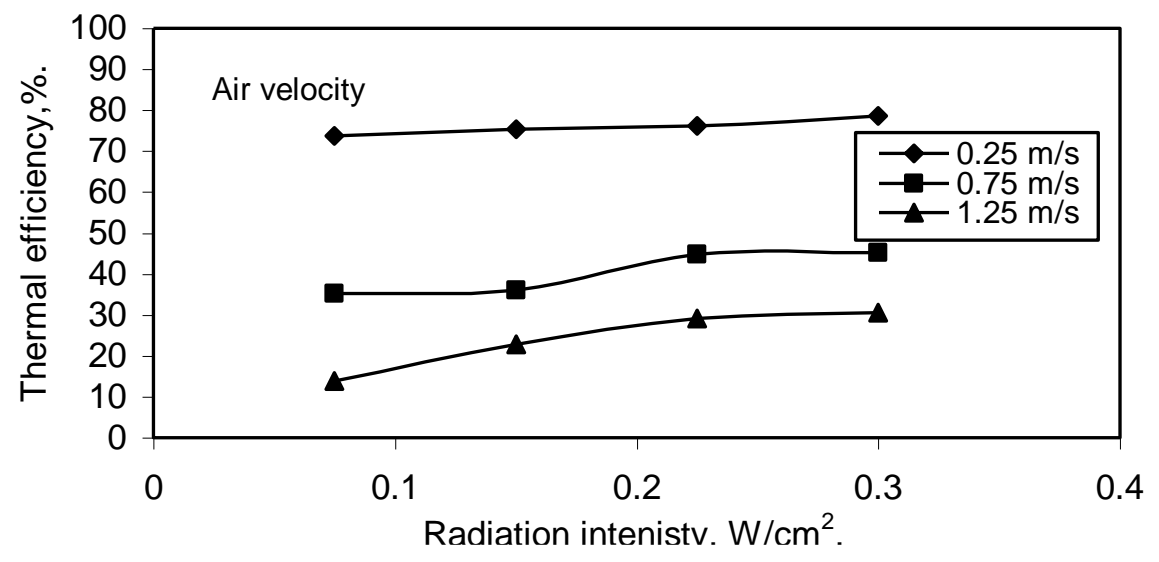

Figure (10): Thermal efficiency of the drying process at different radiation intensity and air velocity.

Parakash et al. (2004) for carrot. Changing the radiation intensity from 0.075 to $0.3 \mathrm{~W} / \mathrm{cm}^{2}$ at the minimum air velocity of $0.25 \mathrm{~m} / \mathrm{s}$ increased the rehydration ratio from 1.625 to 2.2 , while it was increased from 1.457 to 1.907 at the maximum air velocity of $1.25 \mathrm{~m} / \mathrm{s}$.

\section{Colour change of garlic slices:}

Figures (12and 13) present the effect of infrared radiation and air velocity on the colour change and the hue angle of the garlic slices. The figures showed an increase in colour difference and a decrease in hue angle by increasing infrared radiation. 


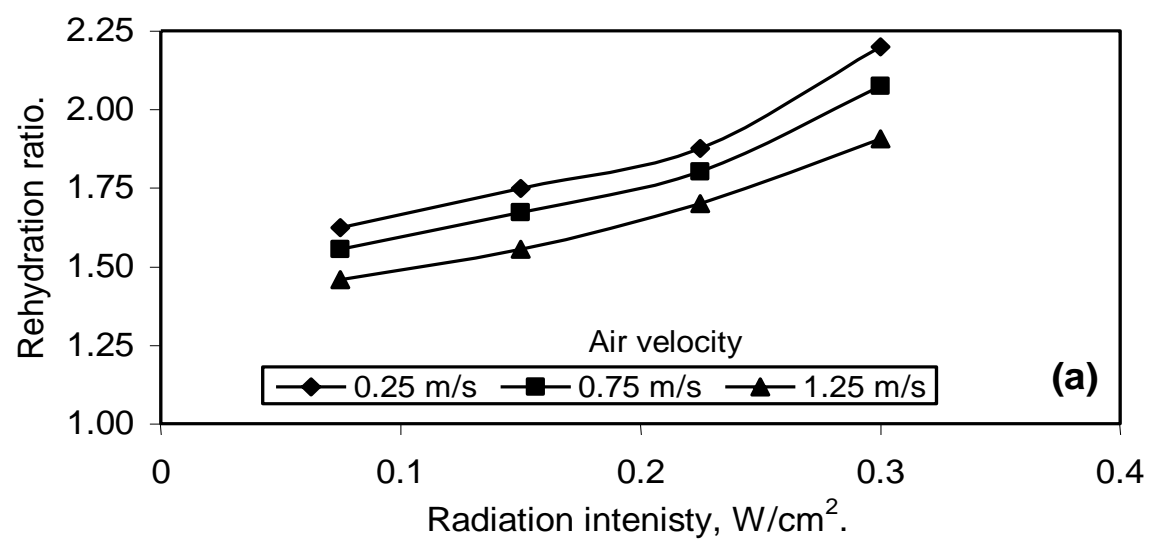

Figure (11): Effect of infrared radiation intensity on the rehydration ratio of garlic slices at different air velocity.

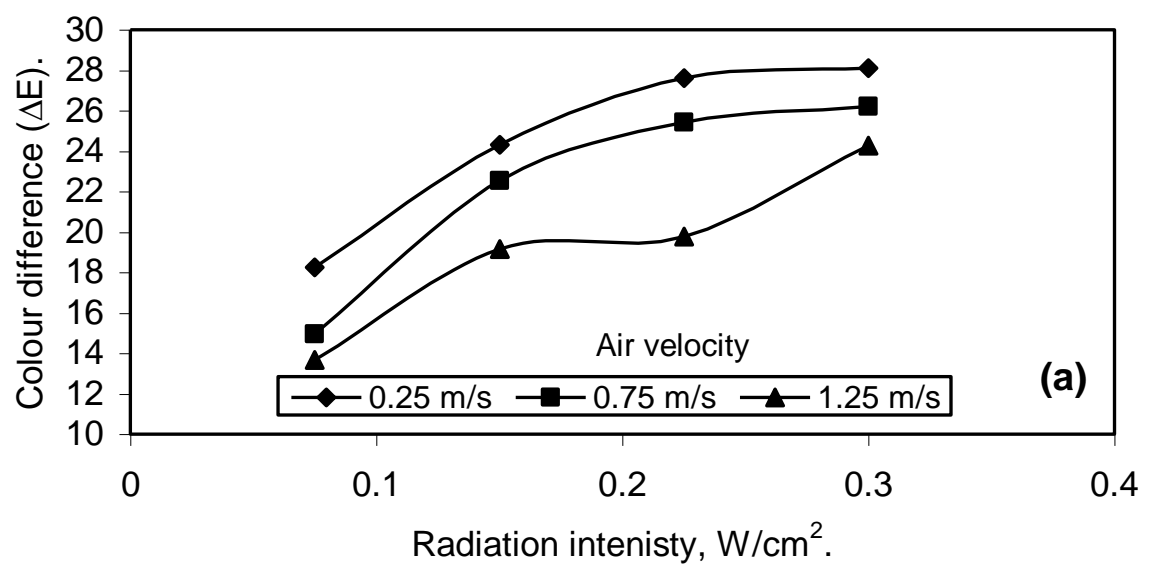

Figure (12) Effect of infrared radiation intensity on the colour difference of the garlic slices at different air velocity. 
At the minimum air velocity of $0.25 \mathrm{~m} / \mathrm{s}$, changing the radiation intensity from 0.075 to $0.3 \mathrm{~W} / \mathrm{cm}^{2}$ increased the colour difference from 17.75 to 27.15 and decreased the hue angle from 76.08 to 65.32 degree. While, at the maximum air velocity of $1.25 \mathrm{~m} / \mathrm{s}$, the colour difference increased from 13.97 to 24.3 and the hue angle decreased from 82.4 to 73.2 degree.

\section{Flavor Strength of Garlic Slices:}

Figure (14) presents the effect of infrared radiation and air velocity on flavor strength of the garlic slices. The figure showed a decrease in the flavor strength by increasing the radiation intensity and decreasing air velocity.

Changing the radiation intensity from 0.075 to $0.3 \mathrm{~W} / \mathrm{cm}^{2}$ at the minimum air velocity of $0.25 \mathrm{~m} / \mathrm{s}$ decreased the flavor strength from 4.36 to $3.62 \mathrm{mg} / \mathrm{g}$ dry matter. While, at the maximum air velocity of $1.25 \mathrm{~m} / \mathrm{s}$, the flavor strength decreased from 5.37 to $4.36 \mathrm{mg} / \mathrm{g}$ dry matter. The reduction in flavor strength with the increase of radiation intensity and decrease of air velocity may be due to the increase of garlic slices temperature.

\section{CONCLUSIONS}

Analysis of the results of the present research led to the following conclusions:

1- Drying rate, thermal efficiency, rehydration ratio and the colour difference increased with the increase of radiation intensity, and the decrease of air velocity.

2- Specific energy consumption, hue angle and the flavor strength decreased with the increase of radiation intensity and air velocity.

3- Page model satisfactorily described the drying behaviour of garlic slices and predicted the changes in garlic slices moisture content in comparison with modified page and Henderson and Pabis model.

4- Drying constant of Page model (k) increased and the constant (n) decreased with the increase of radiation intensity and the decrease of air velocity. 


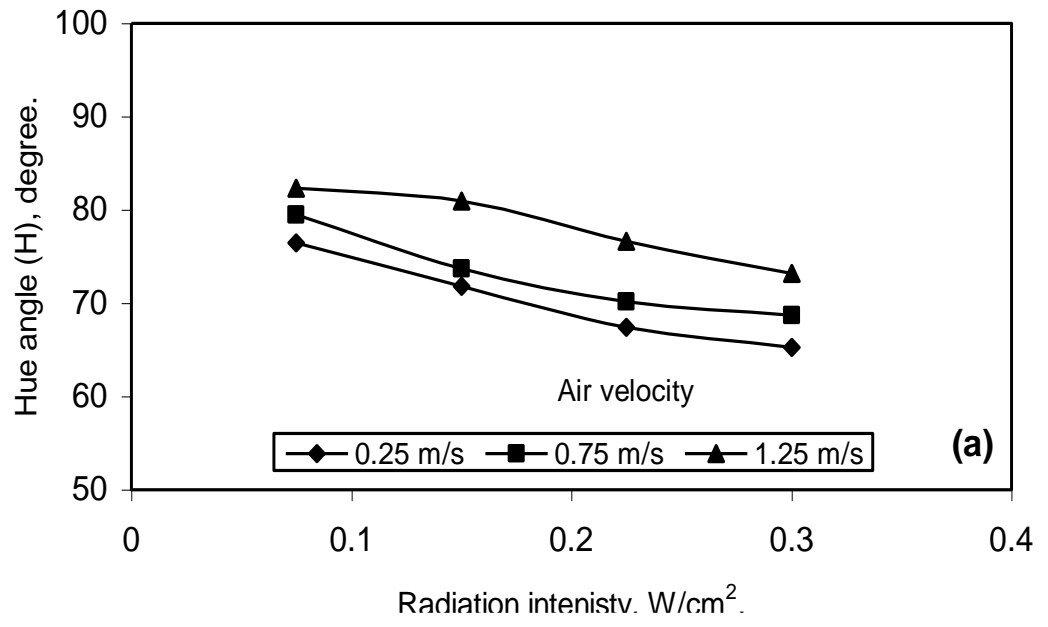

Figure (13): Effect of infrared radiation intensity on the hue angle of the garlic slices at different air velocity.

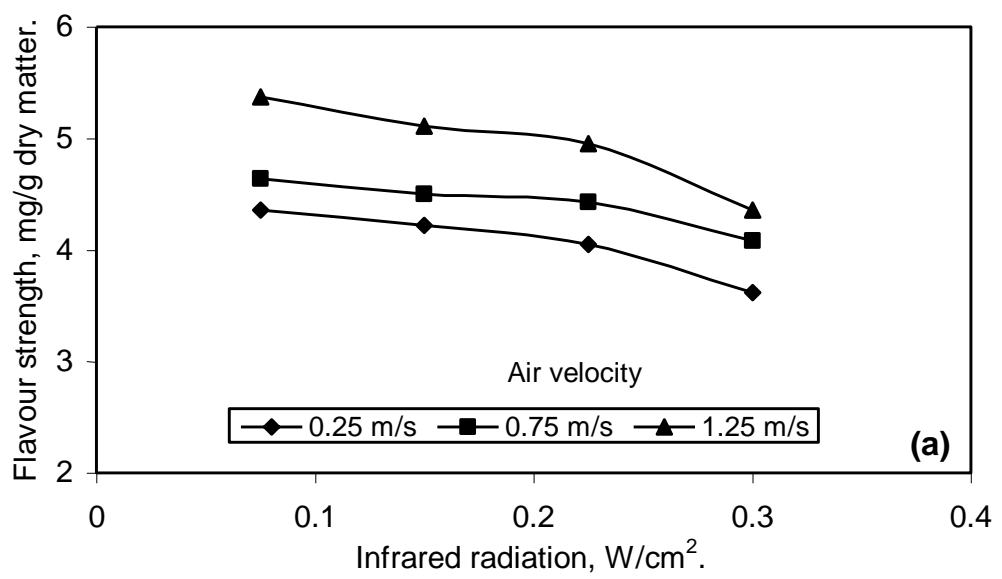

Figure (14): Effect of infrared radiation intensity on the flavor strength of the garlic slices at different air velocity. 


\section{REFERENCES}

Abe, T. and M. Afzal (1997). Thin-layer infrared radiation drying of Rough rice. Journal of Agricultural Engineering Research, 67, 289-297.

Afzal, T. M. and T. Abe (2000). Simulation of moisture changes in barley during far infrared radiation drying. Computers and Electronics in Agriculture, 26, 137-145.

Afzal, T. M.; T. Abe and Y. Hikida (1999). Energy and quality aspects during combined FIR-convected drying of barley. Journal of Food Engineering, 42, 177-182.

A.O.A.C. (1995). Official method of analysis, association of official analytical chemists. Washington, D.C. USA.

Crank, J.(1975). The mathematics of diffusion. Oxford, England: Clarendon Press.

Doymaz, I (2004). Convective air drying characteristics of thin layer carrots. Journal of Food Engineering, 61, 359-364.

Hall, C. W. (1970). Drying farm crops. Agricultural Consulting Associates, Inc., Engineering sepecialists.

Henderson, S. M, and S. Pabis (1961). Grain drying theory. II. Temperature effects on drying coefficients. Journal of Agricultural Engineering Research, 6, 169-174.

IIAS,(2007).Important indicators of agricultural statistics .Economics affairs sector, Ministry of Agricultural and Land Reclamation. volume 1(winter crops).

Jayas, D.S. and S. Sokhansanj (1989). Thin-layer drying of barley at low temperatures. Can. Agric. Eng. 31, 21-23.

Jones, P. (1992). Electromagnetic wave energy in drying processes. In A. S. Mujumdar (Ed.), Drying '92 (pp.114-136). Amsterdam: Elsevier Science.

Mongpraneet, S.; T. Abe and T. Tsurusaki (2002). Accelerated drying of welsh onion by far infrared radiation under vacuum conditions. Journal of Food Engineering, 55, 147-156.

Noomhorm, A. and L. R. Verma (1986). Generalized single layer rice drying models. Transaction of ASAE, 29(2), 587-591. 
Overhults, D. G.; G. M. Whit; H. E. Hamilto and I. J. Ross (1973). Drying soybeans with heated air. Transactions of the ASAE, 16, 112-113.

Ramesh, M. N. (2000). Effect of cooking and drying on the thermal conductivity of rice. International Journal of Food Properties, 3(1), 77-92.

Reys, V. G. and Jindal (1986). Heat treatment of high moisture paddy for temporary storage. D. E. Dissertation A. IT. Bangkok Thailand. Pp. 31- 38.

Pabis, S. and S.M. Henderson (1962). Grain drying theory. III The air grain temperature relationship. J. Agric. Eng. Res. 7, 21-28.

Page, G. E. (1949). Factors influencing the maximum rates of air drying shelled corn in thin layers. M.S. thesis. Department of Mechanical Engineering, Purdue University, Purdue, USA.

Parakash, S.; S. K. Jha and N. Datta (2004). Performance evaluation of balanced carrots dried by three different driers. Journal of Food Engineering., 62, 305-313.

Sacilik, K. and G. Unal (2005). Dehydration Characteristics of Kastamonu Garlic Slices. Biosystems Engineering, 92 (2), 207215.

Shankaranarayana, M. L.; K. O. Abraham; B. Raghavan and C. P. Natrajan (1981). Determination of flavor strength in alliums (onion and garlic). Indian Food Packer, 35: (1), 3 - 8.

Sharma, G.P .and S. Prasad (2006). Optimization of process parameters for microwave drying of garlic cloves. Journal of Food Engineering 75: 441-446.

Tutuncu, M. A. and T. P. Labuza (1996). Effect of geometry on the effective moisture transfer diffusion coefficient. Journal of Food Engineering, 30, 433-447. 


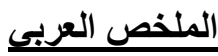

\section{تجفيف شرائح الثوم في طبقه رقيقة باستخدام الأشعة تحت الحمراء}

\section{إسماعيل أحمد عبد المطلب ا محمد مصطفي الخوليج نبيهة حسن أبوا لهناب

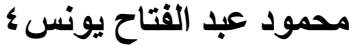

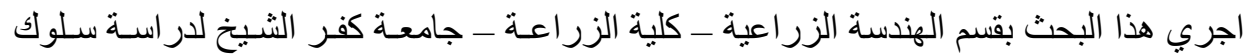

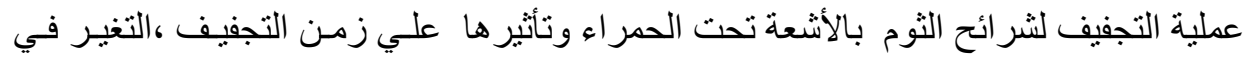

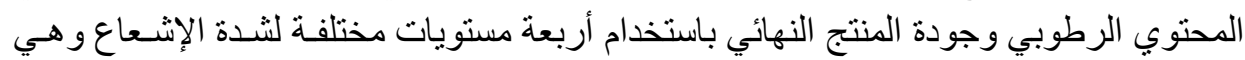

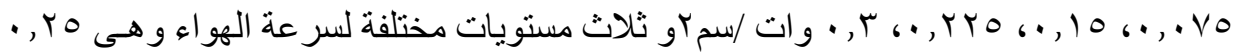

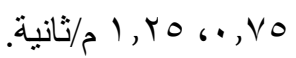

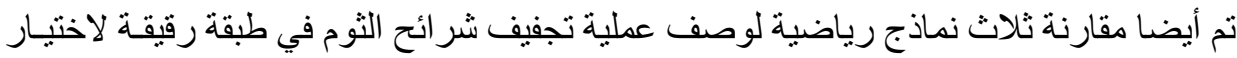

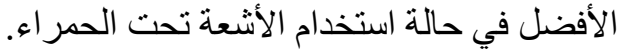

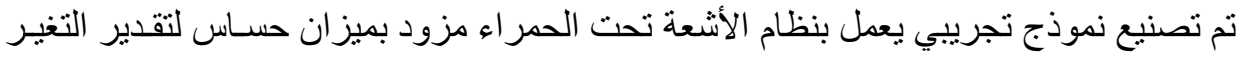

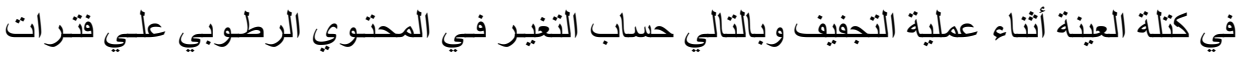

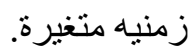
أظهرت النتائج المتحصل علئه أنيها:

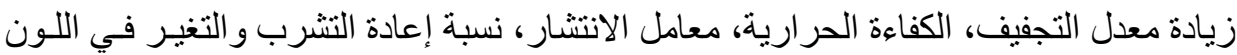

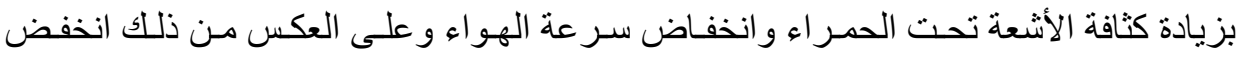

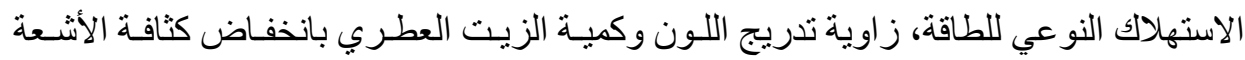

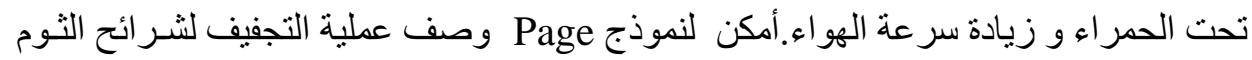

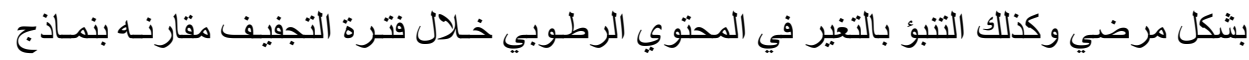

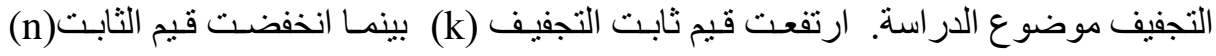

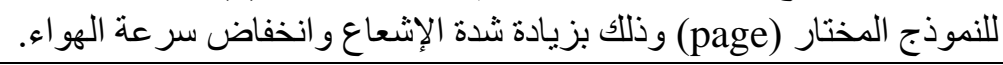

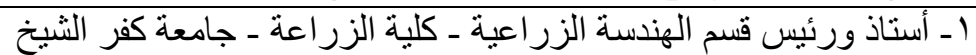

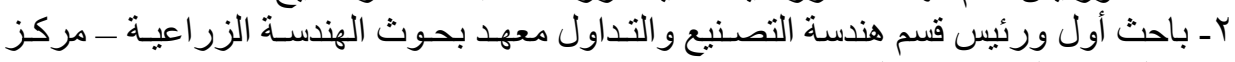

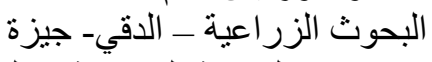

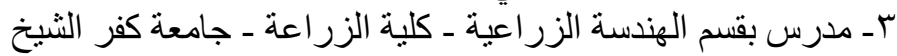

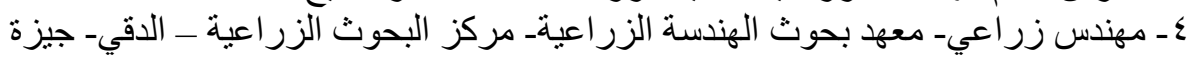

